\title{
A therapeutic community as a relevant and efficient ecclesial model in African Christianity
}

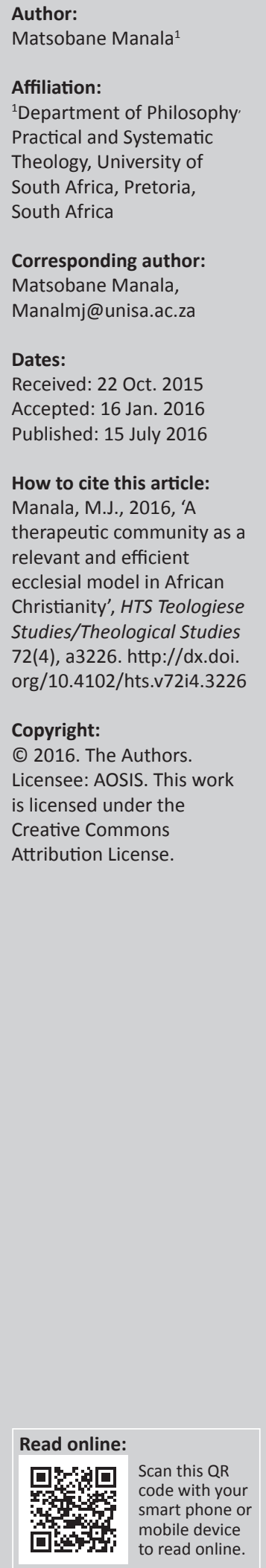

Author:

Affiliation:

${ }^{1}$ Department of Philosophy'

South Africa, Pretoria,

South Africa

esponding author:

Matsobane Manala,

Dates:

Received: 22 Oct. 2015

Accepted: 16 Jan. 2016

blished: 15 July 2016

ow to cite this article:

Manala, M.J., 2016, 'A

relevant and efficient

ecclesial model in African

Christianity', HTS Teologiese

Licensee: AOSIS. This work

is licensed under the

Creative Commons
This article sets forth the argument that Christian ministry in Africa must become socially and culturally informed and constructed or else it will not touch the African soul and thus remain superficial. Black African people aspire above everything else to experience fullness of life and wellbeing here and now, as demonstrated by their greetings that are actually an enquiry into each other's health and an expression of the wish for the other's good health and wellbeing. The mainline churches that operate in Africa should embrace the scripturally sound Christian healing ministry in obedience to Christ's commission to preach the gospel and heal the sick, if they are to prosper. Hence, this article discusses the following eight points, namely, (1) good health and healing as Africans' important aspiration, (2) healing as the work of God and thus of the church, (3) the imperative of serious consideration of and respect for the African worldview, (4) membership decline and mainline churches' loss of influence, (5) rethinking church in African Christianity, (6) the need for the black African church to adopt a therapeutic or healing community ecclesial model in order to position itself strategically to cater for the holistic needs of African (South African) church members and surrounding communities, (7) the rationale of the healing ministry in today's Reformed Church in Africa and (8) the recommended healing ministry. The article closes with a few concluding statements and advice.

\section{Introduction}

This article argues that unless the Christian ministry in Africa is socially and culturally informed and constructed, it will not touch the African soul and thus remain superficial. It means that Christian ministry in Africa should be formulated and practised in a way that resonates with the African social expression and cultural practices. It must learn from the African worldview, to have its message and actions understandable to Africans in their peculiar context.

Practical-theological ecclesiology, according to Heyns (1992:324), busies itself with questions that concern the effective functioning of the local congregation as the manifestation of the church in general in its task of mediating salvation. In Africa, as is the case with other contexts, it is important for the church to have its ministry incarnated in the African cultural milieu (see Imasogie 1993:14; Louw 1994:21-28). In his recent publication, Dames (2014:14) reflects on the discipline of Practical Theology as a contextual endeavour with both an academic and a practical agenda and mission especially in South Africa. Practical theology and Christian ministry need to be context-specific or, as Imasogie (1993:14) calls it, incarnational. Pato (1998:52) points out in this regard that 'the church of Africa and its theology must bear an African stamp'. It means that the worldview or context of black Africans must be respected and the ministry channelled through their idiom, with consideration of their customs and beliefs; otherwise their understanding, appropriation and assimilation of the message will be limited and shallow.

This article progresses by sequentially describing the issues listed in the abstract above. Aware of controversies regarding the healing ministry of various denominations and ministries, I will in conclusion also provide some advice pertaining to a healing ministry that will at all costs (1) avoid miracle mongering and undue controversy, (2) de-individualise the Christian healing ministry and (3) respect black African people's rights and dignity, not capitalising on their gullibility.

The methodology followed in this article is the literature or theoretical research. Literature research is defined as: 'the discussion of existing data and developments within a particular incidence or phenomena. It is aimed at revealing shortcomings, developments and ideas for future research in that field'. ${ }^{1}$ Creswell (2003) articulates the value of literature study thus: 
(1) It shares with the reader the results of other studies that are closely related to the study being reported; (2) it relates a study to the larger ongoing dialogue in the literature about a topic, filling the gaps and extending prior studies; and (3) it provides a framework for establishing the importance of [your] study as well as benchmark for comparing the results of a study with other findings. (pp. 29-30)

Literature on African Christianity and its need for relevant and efficient ministry practices in a context of black (South) Africa is studied. The aim is to describe and emphasise black African Christians' worldview-based need for health and healing and to suggest 'a therapeutic community' as a relevant ecclesial model in African Christianity. Finally, the aim is to recommend a healing ministry for the Maranatha Reformed Church of Christ (MRCC).

\section{Good health and healing as important aspirations of black Africans}

Black Africans are said to greatly aspire fullness of life and wellbeing here and now (Haule 1969:150-151; Maimela 1985:68; Moila 2002:21; Ramashapa 1996:358). In his study among the Zulu people, Moila (2002:21) asserts that they view good health as life itself. This position is confirmed by Osei (2003:168) who says: 'Africans from time immemorial have discovered that to be healthy is to live, and without life there are no human persons'. It is therefore not surprising that black Africans often travel long and tedious journeys in search of cure, healing and good health. They consult medical doctors, sangomas and prophets to ensure that their health and that of their families is intact.

To black Africans, no amount of money is too much in relation to the value of good health. Listening to the resolve of some survivors of the Synagogue Church of All Nations building collapse in Lagos, Nigeria that led to the death of many people including 84 South Africans in September 2014, to continue taking the arduous journeys to the same place is evidence of the value they attach to the healing activities of that church. Manala and Theron (2009:174) contend that '[f]or Africans especially, healing and good health represents God's presence and active involvement in the provision of a better life'. Healing and the healing ministry should thus form an important component of the African Christian church's service.

\section{Healing as the work of God and thus of the church}

Many Africans understand healing as the work of God that is absolutely impossible without him. God is, for example, said to 'lift up the sick' (Mbiti 1970:68). Healing as the work of God is therefore an important task of the church of our Lord Jesus Christ. It can only happen because God permits it and assists in bringing it to realisation (Mbiti 1970:67). This reminds us of God's statement in Exodus 15:26: 'I am the Lord, the one who heals you' (GNB). Mbiti (1970:68) states this fact in superlative terms, citing the Akamba tribe in situations of extreme desperation: 'God is the most superior Physician'. To black Africans, therefore, healing as a holistic concern rests with God and is performed through his empowered messengers. The implication is that the black African church, which is God's dominion, should be the healing agent for God's people. While acknowledging the holistic nature of Christian healing, this article focuses more on physical healing, as adopted in African Christianity. Nevertheless, reference to the holistic nature of the church's healing ministry will be made in some sections of this article, since it is a given in African Christianity.

Eurocentric churches and black African churches perceive and practise healing differently. Highlighting these important differences regarding the healing practice, Van Laar $(2006: 231,240)$ writes: 'In Western society, medicine is practised in the hospital, religion in the church. In Africa, matters are different; healing is an integral part of church life ...', which is the result of Africans' religious belief that dominates the African worldview. Driving in Thabo Mbeki Road in Mokopane recently, I was fascinated by the words: 'Jesus Red en Genees', on the wall of one Pentecostal church. Translated into English the words mean: 'Jesus saves and heals'. The words are a clear articulation of the mission that Jesus gave to his church, namely mediating salvation and healing the sick (see Duncan 1988:63). According to Duncan (1988:117), the church's healing ministry is actually the very reason for the church's existence; he asks rhetorically: 'How can the body of Christ [the church] stand back from a total commitment to the healing ministry when its whole raison d'etre [sic] is to make men and women whole?' Christian healing is according to Duncan one of the core functions of the church. As a genuine practical-theological concern, healing is one of the functions or consequences of pastoral work (Theron, Hestenes \& Dreyer 1999:135). All churches would do well to carry out this mission fully in obedience to Christ's commission to preach the gospel and heal the sick.

The reality is, however, that many mainline churches have greatly neglected and ignored Christ's commission to heal the sick (Manala 2012:268; Manala \& Theron 2009:166-172). As a concerned member and leader of the MRCC, I have observed that this church is among churches that ignore the healing ministry as practised by Jesus of Nazareth. Manala (2012:268), after citing this church's church order on the mission of the church and the functions of its pastorate, states: 'The MRCC ministry to the sick focuses exclusively on spiritual, psychological, emotional [healing] and moral transformation, leaving the physical healing entirely in the hands of medical science'. This, I suppose, is the result of this church's Western origin with its heavy reliance on Enlightenment thinking which refers to:

an age marked by the rise of secularism: the belief that human history as well as contemporary life can be understood without speaking of God or assuming divine activity in human affairs. (Gerkin 1997:44; see also Mwaura 2000:82) 
Aldridge (1991:425) also indicates that when Christianity adopted a natural-scientific approach in its reflection on life, birth and death, which verified human life in the same way it did the physical universe, it effectively rejected the belief in God's supernatural power.

This led to the neglect of the healing ministry, forcing some church members to have double allegiance - secretly attending some healing-ministry-practising church and wearing its healing symbols while still a member of a mainline church. Such a situation deals a deadly blow to the above mentioned 'healing ministry - shunning churches' efficiency and relevance in African Christianity. The MRCC as a black African church must take cognisance of and fully understand the African worldview (Manala 2005:53).

\section{The imperative of consideration of and respect for the African worldview}

Africa is a specific and unique context that requires due recognition and serious consideration by all bodies operating therein (Manala 2012:270). The word recognition is here used in the sense of acknowledgment, appreciation and respect. Heimbrock (2011) states:

Christian theology is devoted to reflection on religion, life and faith; moreover it is a passionate intellectual participation and engagement in life. Engagement with religion is interwoven with culture and everyday-life, [and] connects to the encounter with reality in general. (p. 153)

This position is particularly significant and relevant for this specific article in which I wrestle with the Christian life struggle in the midst of the peculiarly African culture and our contemporary context. It is imperative therefore that the African worldview will be viewed as an important context that needs to be acknowledged and respected. Schwär (2001:79) usefully defines worldview thus: 'Worldview generally refers to a comprehensive philosophy of the world, of human life and of the universe, including cosmology, religion and explanations of existential and empirical phenomena'. It is indeed an important matrix that influences matters in all cultures, as Moila (2002:76), rightly states: 'The worldview lies at the very heart of culture, touching, integrating with, and strongly influencing every other aspect of the culture'. Failure by the church in Africa, to take the African worldview seriously has devastating consequences for that church's qualitative and quantitative growth (see Landman 2008:198-200).

Imasogie (1993:14) believes that Christian theology and ministry must be articulated and practised in forms amenable to African thought in order to effect understanding and commitment to Christ. Imasogie (1993) later elaborates on his earlier alluded superficiality, saying:

For many years many sensitive pastors/theologians in Africa have noticed that in times of crisis, the average African Christian reverts to the traditional African religious practices. In some instances, pastors/priests (theologians, if you please) have themselves fallen victim to this almost irresistible reaction to existential confrontation. (p. 68; cf. Anderson 2000:380)

The African worldview is thus significant for the Christian ministry. As reason for this seeming compulsion for Africans to revert to African survival resources during crisis times, Mugambi (2005:517) says: '[I]t is almost impossible for one to dissociate one's religious heritage from one's total culture'. One of the crises that trouble Africans and from which they seek liberation is disease.

The intense aspiration and search for health and wellbeing, on the one hand, and the neglect of the healing ministry by the mainline churches, on the other hand, seem to present black African Christians with a serious dilemma. This dilemma often leads to what Msomi (2008:157) warns African pastoral counsellors to avoid, namely, a 'schizophrenic existence' saying: 'Many a parishioner is torn between two worlds: the often familiar traditional African view and the world of modern Christianity heavily adorned in Western attire' (cf. Setiloane 2000:46). This constitutes a serious indictment to the Christian ministry. Setiloane (2000), for instance, points to serious pathology that can result from such a situation:

It may be alright and possible to do this in the physical world, that is, to don western clothes and [to] function as such at times, and at others return to the African village and African life. It can, however not be done for long nor with impunity when it comes to religious matters that seek to give meaning to life, here and now, and to death and the hereafter. For people noted for being 'religious people', these are serious issues. Attempts to push them underground, have given rise to a legion of tragedies in both communal and personal life, for example, in the indigenous Church movement, and many cases of individual psychological complications. (p. 46)

The African worldview is characterised by a strong sense of community, mutuality, self-sacrifice for the sake of the other and the belief in God's healing power (cf. Manala 2006:216; Uka 1994:145). At the heart of the African worldview are African traditional religions (Mbiti 1989:59; Teffo 2003:165). Mbiti (1989:59) rightly states: 'African traditional religions provided working answers to the mysteries and life problems and colours all aspects of African life'. The truth of this fact is confirmed by Kasamba (2005:311) who points to the African view of God 'as the ultimate explanation of the genesis and substance of human beings and all things'. This article thus argues that the church that operates in Africa, especially the one serving black Africans, needs to adopt an ecclesiastic model that is more authentically African, because such a model is likely to meaningfully address and solve problems that are typically African (Grundmann 2001:30-31).

Healing is high on the list of those uniquely African concerns for the following reasons: (1) the persistent influence of the cultural religious worldview. In this regard Lugira (2004:62) avers: 'In an African community, religion is the strongest influence upon people's thoughts, acts, and lives'; (2) the 
abject poverty many Africans live in (see Echema 2006:29-30); (3) the craving for wholeness in Africa as a result of lengthy periods of oppression and marginalisation; (4) clearer awareness of brokenness and of the darker sides of human experience; (5) the challenge of the church to make a difference in processes of reconciliation, especially in espousing and engendering forgiveness, retribution (justice), restitution and healing of memories; (6) the prevalence caused by AIDS forces more action towards liberation from this epidemic (see Van Laar 2006:227). Moila (2002:21) provides a further substantive explanation of the attractiveness of healing for Africans, namely that healing is to Africans, 'life itself, which is viewed holistically that is physically, relationally, mentally and supernaturally'. Moila (2002:21) states further that healing ensures the continued existence of the clan, ensuring the clan's future.

In line with the understanding that the church in Africa needs to be a healing community, Msomi (2008:161) suggests that the appropriate Nguni word for pastor should be one that brings out the aspect of healing, instead of umfundisi, which means teacher. Substantiating this suggestion, he states: '... African Christians are not yearning only for an understanding of the doctrines of the Church but they long for therapy originating from God for their troubled bodies and souls' (Msomi 2008:161). This position contradicts that of Calvin, according to Jensen (1963:76), that limits Christian ministry to the 'dispensing of the Word and Sacraments ... or to build[ing] up the church publicly and privately with sound doctrine'. According to Msomi (2008:161), the heart of the Christian ministry should be healing.

\section{Membership decline and loss of influence in mainline churches}

The fact that mainline churches in Africa and elsewhere are in danger of dissipating is common knowledge. The irony is that the decline in membership and influence of these churches occurs during the time when the centre of gravity of Christianity is said to be shifting southwards, that is, towards Asia, Latin America and Africa (see Lenka Bula 2008:290; Onyina 2002:107).

There are various reasons for this decline, but in this article I am interested in the shunning of the healing ministry as cause. Surprisingly, there is phenomenal growth in the African Initiated Churches (AICs) which Onyinah (2002:107) ascribes to their efficient dealing with life threats, saying reasons for that: '... significantly include the way the Africans have attempted to deal with their threatening fears, especially witchcraft'. The church's mediation of healing is, according to Mwaura (2000:82), one magnet that draws millions of members to 'the prophet-healing African Independent Churches' because, as earlier mentioned, one of Africans' greatest aspirations is the abundant life and wellbeing here and now.

Consequently, all community development entities in Africa, including the church, need to participate in the provision of the requisite abundant life and wellbeing through dealing efficiently with threats to life such as diseases and other misfortunes. It seems that this is the responsibility that some African mainline churches have neglected, at their own peril. Something must indeed have gone wrong in the doctrinal formulations and ministry praxis in these churches that once had the greatest following and influence. Landman (2008:198200) ascribes the loss of growth and influence of the Uniting Reformed Church in Southern Africa in the HoedspruitAcornhoek-Bushbuck Ridge area of South Africa, after 50 years of domination, to among others, 'the inability of the Reformed Churches to satisfy the healing needs of black believers'. This inability was most probably the result of the Enlightenment-influenced teaching of Reformed Churches' founding fathers like John Calvin who is said to have believed and taught that 'the age of miracles is past' (Jensen 1979:131). Such belief and teaching are undoubtedly alienating to black Africans who subscribe to the African religious worldview, for whom the unseen and supernatural realm are a reality to be reckoned with. It is also important to note that the abovementioned conviction does not come from the Bible, as Jensen (1979:132) points out: 'The Bible nowhere indicates that the miraculous is to cease when the apostolic age is over. On the contrary, there is evidence that this divine effusion is to be coterminous with Church history'. The early Christian church believed, trusted and practised the healing ministry as attested to in James 5:14, 15. The exponential growth of the church in those early years was the result of the practice of the healing ministry. Such growth as a result of the church's practice of the healing ministry is today found in AICs, Pentecostal churches and Charismatic movements that have latched onto the magnetic force of healing and wholeness. It seems proper at this stage, therefore, to reflect on the need to rethink the Christian church in Africa.

\section{Rethinking the Christian church in Africa}

The Christian healing ministry is, according to Kelsey (1970:112) an essential heritage of the Christian church. Kelsey (1970:112) asserts: 'And Jesus specifically sent his followers out to practice such a ministry, directing them to expect healing to occur as part of being his followers. They are to teach, preach and heal'. Duncan (1988:8) as well, supports the declared centrality of Christian healing in his reference to the healing ministry as the 'essential Christianity expressed in Christ's dual but distinctive command to the disciples: "Preach as you go, saying, the Kingdom of heaven is at hand; heal the sick"' (Mt. 10:7-8). This Christian legacy was wrongly overlooked by the later church, the omission that constituted a serious digression from Christ's commission, with destabilising consequences. Cobb Jr's book (1997) titled, Reclaiming the church: Where the mainline church went wrong and what to do about it, affirms the oversight that occurred in these once powerful churches. The book is about the need for church renewal. Cobb (1997) rightly states:

We need to look at ourselves realistically and diagnose our failures honestly. We need then to see whether we nevertheless 
have a continuing role to play that warrants our efforts to survive and even grow. And if we decide that we do have such a role, then we need to consider what changes are needed if we are to reverse the current decay. (p. 5)

Nürnberger (Manala \& Theron 2009:169) too, calls for an intense scrutiny and extensive reconceptualisation by mainline churches, of their theological heritage in the face of African spirituality and religious discourse in our changing times. A thorough critical introspection by the African church in this at the crossroads reality of her life and work is in order. This critical introspection must lead to the 'critically contextual' (Brueggemann 1991:178) lifestyle.

Looking at the MRCC realistically, I realise that Cobb's assessment and suggestion need to be heeded. A realistic investigation of the MRCC reveals that unless some serious corrective action is taken quickly the church may disappear before our very eyes. Nürnberger (2007:13), referring to the failure of what he calls classical theology, with reference to the mainline theology, states: 'It could be argued that classical theology might have done a great job for medieval Europe but has failed to do so for Africa'. New perspectives are thus required for the church in African Christianity. Looking at the communal nature of African communities, the systems perspective seems to be the model that will likely successfully address African needs especially with regard to health and wellbeing.

\section{The black African church as a therapeutic community}

The force of ubuntu as a cohesive, extremely communal, mutual and care-inspiring pillar of strength among Africans is sure to influence people's health - psychologically, physically and spiritually - quite positively. Baloyi and Makobe-Rabothata (n.d.:237) rightly aver: 'Traditional Africans understand their being-in-the-world as a qualitative tapestry of connected systems which deal with life issues collectively and collaboratively'. The African collective mode of existence inevitably influences African life and work in very therapeutic ways. The church in Africa thus needs to adopt a new ecclesial model that I call a therapeutic community model in line with McRae, Carey and AndersonScott's study (1998:778). Their study identified important therapeutic factors and their functioning in the Black churches in America. These churches are basically influenced by their African heritage and traditional religious worldview (McRae et al. 1998:778).

For lack of time and space, I state these factors without much elaboration. They are group cohesion, which is viewed as 'the glue that often keeps members returning to church, even when they are unhappy with certain aspects of the experience'; supportive factors (i.e. hope, acceptance, universality and altruism) - representing the Black church's service as 'a social network where individuals obtain assistance in handling day-to-day living problems ...'; selfrevelation factors (i.e. self-disclosure and catharsis) which 'provide an emotional outlet and respite from the burdens of everyday living and crisis events'; learning from others 'Many of the activities found in the church (e.g. Bible study, observing behaviors of those in leadership roles, participation in various structured activities) are examples of cognitive and behavioral learning' and psychological factors - 'In Black churches, as in all groups, it is possible for a person to interact and receive feedback on his or her behaviour' (McRae et al. 1998:782-786).

Such a model provides helping tools of mutual support and promises to help Christians overcome the situation of church members reverting back to African traditional religious means of survival during times of crises (Imasogie 1993:68). Black churches, according to McRae et al. (1998:780), for instance, 'provide an array of emotional and learning experiences and embody therapeutic factors that enhance group cohesion and promote empowerment and social change'.

The notion of churches as therapeutic communities is also affirmed by Van Laar (2006) in an article entitled: 'Churches as healing communities: Impulses from the south for an integral understanding of healing' (see also Duncan 1988). According to Van Laar (2006:231) in the aforementioned article, healing in Africa takes place in the church unlike in the West where healing takes place in hospitals and medical centres (see also Dreyer 2008:17). The church as a faith community is a unifying reality; yes a close-knit community, that is, a lively koinonia whose task it is to glorify the Almighty God, to witness to the salvific presence of Jesus Christ through his Holy Spirit and to call humanity in obedience to Christ's commission, to salvation, healing and liberation. Dames (2014:14), contends that the communal conversational context of Hermans is relevant to the African (South African) context. The African (South African) context's ubuntu foundation with its values of communality, mutuality, love and mutual respect would be the most likely place for the church to function efficiently and effectively as a true healing community.

Black African churches are therefore, according to McRae et al. (1998), rightly to be understood as:

open systems that operate and develop differently and as therapeutic settings that provide a safe place for emotional expression ... In sum, the Black church is a form of group activity that provides healing and other health and learning benefits to its membership. (p. 780)

The Black church is thus according to this insight a redeemed community whose mission is to effect salvation, healing and liberation to those under the strain of evil, diseases and sociopolitical oppression and impoverishment. McRae et al. (1998:780) continue to define the Black church from a systems perspective, saying: 'For systems to survive and thrive, they must be adaptive to their environment while protecting their internal subsystems'.

Black churches do not have to feel compelled to follow a particular ecclesial model. Brueggemann (1991:28) teaches us 
that no church is to be forced into a particular model. Brueggemann's view is indeed enabling and empowering to the process of reconceptualisation of the church and its ministry especially in African Christianity, based on the existential experiences and needs of its members. It seems proper therefore to suggest that for the church operating in African Christianity to flourish in the 21st century, the therapeutic community model is the most suitable. Mainline churches that, unlike the African Initiated and Pentecostal churches, still lag behind should adapt to this model or they will die. Van Laar (2006:240) points in this direction when he states that the holistic healing task of the church should be utilised to describe the 21st century church's core activities or religious actions.

This article therefore suggests that a therapeutic or healing community model is the most relevant and efficient ecclesial model in African Christianity as an African worldview-based ecclesial model. It seems to me that adaptation to the therapeutic community ecclesial model is not an option for the church in African Christianity. According to Van Laar (2006:230), the ecumenical movement helped in reviving interest in the church's healing ministry and in the reshaping of the church 'as a healthy and healing community' via the 1964 World Council of Churches and Lutheran World Federation-organised Tübingen Consultation's stance that led to the emergence and growth of the conviction that 'the church must not limit itself to technical medical treatment, but that the church's calling was itself to be a healthy and healing community'. The view held by the WCC, of the healing ministry as focused on justice, was later broadened, following the insistence of the more orthodox and evangelical member churches, to a more holistic one. Consequently, the Harare Assembly in 1998 adopted the following position (Van Laar 2006):

The churches recognise that they are called by God, through the example of their Lord and through the power of the Holy Spirit, to be healing communities and to take part in the ministry of healing. In a broken world, full of war, injustice, poverty, exclusion and illness, the churches have the possibility to bring healing, to find forgiveness and wholeness, and to propagate these gifts in society., (p. 230)

Through active provision and modelling of support, guidance, healing and reconciliation this move of the ecumenical movement represents a realistic assessment of the role of the 21st century church, especially in African Christianity.

\section{The rationale of the healing ministry in today's Reformed Church in Africa}

According to Jensen (1963), one of the factors Calvin drew from Scripture concerning the nature of the ministry was that:

Both bishops and presbyters had to devote themselves to the dispensing of the Word and Sacraments ... It was a principle of long standing in the church that the primary duties of a bishop were to feed his people with the Word of God, or to build up the church publicly and privately with sound doctrine. (p. 76)

However, the church has, apart from this significant task, also a health care ministry as its mission. Many gospel accounts reveal the deep-lying concern of Jesus Christ for the sick (Barclay 1975:390). Van der Poel (1999:16) states the result of this concern quite well: 'Healing of illnesses of any kind (cf. Mk 3-4) was a significant part of his ministry'. It is important to note the reasons for Jesus' active practice of the healing ministry. Kelsey (1970) states two basic reasons namely:

1. He saw that sickness had a destructive effect on human life and he cared about human beings ... His healing sprang from his compassion for men [sic], his feeling that he wanted to relieve them of their misery.

2. He was hostile to sickness and to that which made men [sic] sick. Most sickness was seen by Jesus, not as a chastening visitation of God but as the work of the 'evil one' and his minions; it was to be a battle to the death against this power that afflicted the children of men [sic]. The mentally ill were believed to be directly possessed by this evil power. The physically ill also seemed to be under the influence of an evil reality - call it demons, Satan, or simply something destructive and uncreative, the opposite of the spirit and life of God. (p. 113)

This resonates quite well with the African worldview-based belief about and experiences of illnesses (Moila 2002:22). Van der Poel (1999:16) states further that this caring for the sick later became the concern of the church: 'The Acts of the Apostles show that the same concern was passed on to the early Christian communities'. It means that Jesus gave his later followers, part of whom is the contemporary church, a healing commission as evidenced also in other scriptural passages like Matthew 10:7, 8 and Luke 10:8, 9. According to MacNutt (1999), Christ came to do the following basic things:

1. To give us a new life, a loving relationship of union with his Father and with himself, through the Holy Spirit.

2. To heal and free (save) us from all those sick elements in our lives that need to be transformed so that the new life may freely enter in. (p. 40)

It means that Christ came to save and to heal humankind. If it is true that the church is Christ's historical form of existence (Healy 2008:2570), then she has the abovementioned two basic tasks as her obligation and responsibility. Sicknesses are a serious cause for human brokenness even in our day. The church as the body of Christ is expected to follow his teachings and act as his ambassador in the world. The church needs to take the evil that manifests in sicknesses seriously to the extent of participating in Godly efforts to restore health and wellbeing to broken humanity.

\section{The recommended healing ministry}

The proposed healing ministry should be holistic, catering for psychological, spiritual and physical needs of members 
and should collaborate with other health care functionaries in the community. The following framework is important for the envisaged healing ministry, namely, (1) the significance of human solidarity, (2) the need for human contact with God for health, (3) the dependence of the healing action upon God's will and (4) healing in Africa as a holistic concern.

A brief reflection on these four components of our framework is in order.

\section{The significance of human solidarity in the healing ministry}

The relational aspect of health is appropriate in the African context. The church must therefore engage in and practise the healing ministry in recognition of the human need for solidarity that the church as a healing community is capable of offering (Manala 2006:223). Maddocks (1990:4-5) rightly states: 'neither of us can talk about total health in isolation from the other'. This is in line with what the apostle Paul explains in 1 Corinthians 12:26: the state of human existence as interwoven in a web of life. This is known in Africa where relationships are central to individual health and happiness. Health is therefore founded on sound inter-human relations and meaningful interdependence. The church needs to organise and facilitate this healing web of relationships. This is possible when the church has embraced her calling as a healthy and healing community

\section{The need for human contact with God for health}

Health is found in situations of continued human contact with God. This resonates with the African belief that places God at the centre of human life in contrast to the Enlightenment thinking which maintains that human life and history can be understood without assuming God's involvement. Maddocks (1990:5) cites Carl Jung as saying: 'there is a purposeful centre of reality which man [sic] needs to be in conscious contact for his [sic] full health'. Maddocks concurs: 'Man [sic] is seldom in sound physical and mental health unless he can find some way to relate to this centre of being whom he [Jung] calls God'. Human health is, according to this insight, found in sound humanGod relationship and in trusting human reliance upon God's grace and Spirit.

\section{The dependence of the healing action upon God's will}

The church as the creation of God's Word and Spirit must accept and practise the Christian healing ministry to care for the sick members, enhance their health and improve the quality of their lives (Manala 2006:224). The Christian healing ministry is in essence humbly asking Jesus Christ what to do about any disease and doing it that he might bring the required wholeness. It is not a God's handtwisting exercise for him to do what we want; it is rather praying: 'Thy will be done on earth as it is in heaven' (Mt 6:10). The Christian healing ministry should thus be practised in recognition of God's sovereignty, not as usurping of his control.

\section{Healing in Africa as a holistic concern}

Healing in Africa should be understood and accepted as a holistic concern. This is clear from Berinyuu's insistence (1988:31) that health in Africa is '[w]ellbeing of mind, body and spirit; living in harmony with one's neighbour, the environment and oneself and in all levels of reality ...' This resonates with the truth that 'God is not concerned just with a person's soul but with the total person. God's salvation and healing make us whole persons'. ${ }^{2}$ Western medicine is therefore at times experienced by Africans as inadequate (see Griffiths \& Cheetham 1989:297; see also Manala 2006:231).

\section{Conclusion}

It has been clearly pointed out and argued that the church in Africa has to embark on the healing ministry both as her Christian imperative and as a call to liberate black African Christians from diseases and various other misfortunes. I assume that this will happen quite naturally with the African church's successful adoption of a lively therapeutic community model. Let me in conclusion also provide some advice in terms of the implementation of the envisaged healing ministry in the MRCC:

- Healing and liberation are to be mediated through the preaching, worship, prayer, healing and exorcism services within the fellowship of the believers, for further edification of the faithful, to God's glory and human peace and happiness.

- The healing ministry has to be based on sound theology to avoid unnecessary controversy. It has to be biblical, respectful of human rights and human dignity.

- It must be run not by an individual, but by a carefully selected and trained team under the leadership of the pastor and the church council.

- The healing ministry team should promote and instil good relationships with God, relatives, within the community, with self and the environment.

- It should offer pastoral care and counselling.

- It should conduct healing services within the worship context, hospitals, homes, hospices and so forth.

- It should conduct follow-up care and prayers after hospitalisation and during the recuperation period.

I conclude with two quotations from Van Laar and Msomi respectively: 'In Western society, medicine is practised in the hospital, religion in the church. In Africa, matters are different; healing is an integral part of church ...' (Van Laar 2006:231). ' ... African Christians are not yearning only for an understanding of the doctrines of the Church but they long for therapy originating from God for their troubled bodies and souls' (Msomi 2008:161). It is therefore recommended that the Christian church in Africa should adopt and maintain the therapeutic ecclesial model.

2.www.walnuthillsbaptist.com/sermon/christ3.doc viewed on 19 December 2006 . 


\section{Acknowledgements Competing interests}

The author declares that he has no financial or personal relationships which may have inappropriately influenced him in writing this article.

\section{References}

Aldridge, D., 1991, 'Spirituality, healing and medicine', Review article in British Journal of General Practice 41, 425-427.

Anderson, A., 2000, 'The gospel and African religion', International Review of Mission 2000, 373-383. http://dx.doi.org/10.1111/j.1758-6631.2000.tb00218.x

Baloyi, L. \& Makobe-Rabothata, M., n.d., 'An African conception of death: A cultura implication', viewed 4 September 2014, from http://iaccp.org/sites/default/files/ stellenbosch_pdf/Baloyi.pdf. 232-243

Barclay, W., 1975, The gospel of Mark: The daily study Bible, Saint Andrews Press, Edinburgh.

Berinyuu, A.A., 1988, Pastoral care to the sick in Africa: An approach to transcultura pastoral theology, Peter Lang, Frankfurt.

Brueggemann, W., 1991, 'Rethinking church models through Scripture', Theology Today 48(2), 128-138. http://dx.doi.org/10.1177/004057369104800202

Cobb, J.B., Jr, 1997, Reclaiming the church: Where the mainline churches went wrong and what to do about it, Westminster John Knox Press, Louisville, KY.

Creswell, J.W., 2003, Research design: Qualitative, quantitative and mixed method approach, 2nd edn., Sage, Thousand Oaks, CA.

Dames, G.E., 2014, A contextual transformative practical theology in South Africa, AcadSA Publishing, Parrow.

Dreyer, J.S., 2008, 'Practical Theology and human well-being: An exploration of a multidimensional model of human action as conceptual framework', Practical Theology in South Africa 23(3), 3-22.

Duncan, D., 1988, Pastoral care and ethical issues, health and healing: A ministry to wholeness, Saint Andrews Press, Edinburgh.

Echema, A., 2006, Anointing of the sick and the healing ministry: The Nigerian pastora experience, IKO, Verlag für Interkulturelle Kommunikation, Frankfurt am Main.

Gerkin, C.V., 1997, An introduction to pastoral care, Abingdon Press, Nashville, TN.

Griffiths, J.A. \& Cheetham, R.W.S., 1989, 'Priests before healers: An appraisal of the isangoma or isanusi in Nguni society', in D. Dube, G.C. Oosthuizen, S.D. Edwards \& W.H. Wessels (eds.), Afro-Christian religion and healing in Southern Africa, pp. 295-303, Edwin Mellen Press, Lewiston, NY.

Grundmann, C.H., 2001, 'Healing: A challenge to church and theology', International Review of Mission 90(356-357), 26-40. http://dx.doi.org/10.1111/j.1758-6631. 2001.tb00257.x

Haule, C., 1969, Bantu 'witchcraft' and Christian morality: The encounter of Bantu uchwai with Christian morality: An anthropological and theological study, Nouvelle revue de science missionnaire, Supplementa, vol. 16, SchöneckBeckenried, Immensee, SZ.

Healy, N.M., 2008, 'The logic of Karl Barth's ecclesiology: Analysis, assessment and proposed modifications', Modern Theology 10(3), 253-270. http://dx.doi.org/ 10.1111/j.1468-0025.1994.tb00040.x

Heimbrock, H.G., 2011, 'Practical theology as empirical theology', International Journal of Practical Theology 14, 153-170. http://dx.doi.org/10.1515/ijpt. 2011.013

Heyns, L.M., 1992, Structures in practical theology: Only study guide for PTA200-W by J.A. Wolfaardt, H.J.C. Pieterse, J.T. De Jongh van Arkel, M. Hestenes, J.P.J. Theron, G.A. van Wyk, L.M. Heyns \& J.S. Dreyer, University of South Africa, Pretoria.

Imasogie, O., 1993, Guidelines for African theology in Africa, Africa Christian Press, Achimota.

Jensen, P.F., 1963, 'The ministry in the early church as seen by Calvin', Evangelical Quarterly 68-78, viewed 20 February 2015, from http://biblicalstudies.org.uk/ pdf/eq/1963-2_068.pdf

Jensen, P.F., 1979, 'Calvin, Charismatics and miracles', Evangelical Quarterly 131-143, viewed 05 March 2015, from http://biblicalstudies.org.uk/pdf/eq/1979-3_131.pdf

Kasamba, A.E., 2005, 'The impact of an African spirituality and cosmology on God images in Africa: A challenge to practical theology and pastoral ministry', International Journal of Practical Theology 9(2), 300-323.
Kelsey, M.T., 1970, 'The healing ministry within the church', Journal of Religion and Health 9(2), 105-122. http://dx.doi.org/10.1007/BF01532387

Landman, C., 2008, 'Farm ministries in the Hoedspruit area: Past and present', Studia Historiae Ecclesiasticae 34(2), 187-201.

Lenka Bula, P., 2008, 'The shift of gravity of the church to sub-Saharan Africa: Theological and ecclesiological implications for women', International Journal for the Study of the Christian Church 8(4), 290-304. http://dx.doi.org/10.1080/ 14742250802383195

Louw, D.J., 1994, Illness as crisis and challenge: Guidelines for pastoral care, Orion Publishers, Halfway House.

Lugira, A.M., 2004, African religion, World religions series, rev. edn., Facts on File, New York.

MacNutt, F., 1999, Healing, Ave Maria Press, Notre Dame, IN.

Maddocks, M., 1990, The Christian healing ministry, SPCK, London.

Maimela, S.S., 1985, 'Salvation in African traditional religions', Missionalia 13(2), 63-77.

Manala, M.J., 2005, “God is the most superior physician": Conqueror of witches and great restorer of health in Africa', Practical Theology in South Africa 20(2), 53-71.

Manala, M.J., 2006, 'The church's ministry to the sick in a black South African context', DTh thesis, University of South Africa.

Manala, M.J., 2012, 'Healing: An essential core function of the church in African Christianity', Theologia Viatorum 36(2), 267-292.

Manala, M.J. \& Theron, J.P.J., 2009, 'The need for the healing ministry in the Maranatha Reformed Church of Christ', Missionalia 37(2), 165-179.

Mbiti, J.S., 1970, Concepts of God in Africa, SPCK, London.

Mbiti, J S., 1989, 'God, sin and salvation in African religion', Journal of Interdenominational Theology Centre 16(1), 59-68.

McRae, M.B., Carey, P.M. \& Anderson-Scott, R., 1998, 'Black churches as therapeutic systems: A group process perspective', Health Education \& Behavior 25(6), 778-789. http://dx.doi.org/10.1177/109019819802500607

Moila, M.P., 2002, Challenging issues in African Christianity, CP Powell Bible Centre, Unisa, Pretoria.

Mouton, J., 2001, How to succeed in your Master's and Doctoral Studies: A South African guide and resource book, Van Schaik Publishers, Pretoria.

Msomi, V.V., 2008, Ubuntu contextual African pastoral care and counselling: With reflections and dialogues on Zulu case studies in a cross-cultural perspective, $\mathrm{CB}$ Powell Bible Centre, Unisa, Pretoria.

Mugambi, J.N.K., 2005, 'Christianity and the African cultural heritage', in O.U. Kalu (ed.), African Christianity: An African story, pp. 716-775, Department of Church History, University of Pretoria, Pretoria.

Mwaura, P.N., 2000, 'Healing as a pastoral concern', in D.W. Waruta \& H.W. Kinot (eds.), Pastoral care in African Christianity, pp. 72-100, Acton Publishers, Nairobi.

Nürnberger, K., 2007, The living dead and the living God: Christ and the ancestors in 0 changing Africa, Cluster Publications, Pietermaritzburg.

Onyinah, O., 2002, 'Deliverance as a way of confronting witchcraft in modern Africa: Ghana as a case history', Asian Journal of Pentecostal Studies 5(1), 107-134.

Osei, M.A., 2003, 'Witchcraft in the religion of the Hlubi of Qumbu: Focussing on the issues of sickness and healing in the society', DLitt et Phil thesis, University of South Africa.

Pato, L.L., 1998, 'The Anglican and Africanisation: The legacy of Robert Gray', Journal of Theology for Southern Africa 101, 49-57.

Ramashapa, J.M., 1996, 'Northern Basotho world view: A theological reflection', NGTT XXXVII(2), 353-359.

Schwär, G.H., 2001, 'The relationship between belief, religious orientation and existential meaning', PhD thesis, Vista University.

Setiloane, G.M., 2000, African theology: An introduction, Lux Verbi BM, Cape Town.

Teffo, L.J., 2003, 'Healing: An enduring feature of African religion(s)', Theologia Viatorum 27(1), 165-182.

Theron, J.P.J., Hestenes, M.E. \& Dreyer, J.S. (eds.), 1999, First steps in practical theology: Only study guide for CGM112P, University of South Africa, Pretoria.

Uka, E.M., 1994, 'Christ's healing ministry: A challenge to the church in Africa', in E. Lartey, D. Nwachuku \& K. wa Kasonga (eds.), The church and healing: Echoes from Africa, pp. 138-153, Peter Lang, Frankfurt am Main.

Van der Poel, C.J., 1999, Wholeness and holiness: A Christian response to human suffering, Sheed \& Ward, Franklin, WI.

Van Laar, W., 2006, 'Churches as healing communities: Impulses from the south for an integral understanding of healing', Exchange 35(2), 226-241. http://dx.doi. org/10.1163/157254306776525708 